\title{
The Impact of E-Planning Program Quality, Implementation of Internal Control System and Leadership Style on the Performance of State Civil Apparatur (Study in Department of Education of East Nusa Tenggara)
}

\author{
Emilia Hesti Tandi; Nurkholis; Imam Subekti \\ Master Program in Accounting, Faculty of Economic and Business, Brawijaya University, Indonesia
}

http://dx.doi.org/10.18415/ijmmu.v6i2.599

\begin{abstract}
The performance of the State Civil Apparatur (Aparatur Sipil Negara / ASN) is a crucial factor that must be continuously improved in order to support the regional development. This study aimed to investigate the impact of the quality of E-planning program (X1), the implementation of internal control systems (X2) and leadership style (X3) on the performance of state civil apparatur (Y). This study used quantitative method. The population were 100 employees in the department of education of the East Nusa Tenggara province. Furthermore, the sampling technique used was total sampling. Data collection techniques were carried out using questionnaire. The research data were analyzed using Partial Least Square (PLS) method. The results demonstrated the value of t statistics 2.431 on the variable of EPlanning program quality, 2.701 on the internal control system, and 6.639 on the leadership style. Since coefficients were more than the standard ( $\mathrm{t}$ table) 1.96 and were positive. Thus, it can be concluded that there was a positive and significant impact of each independent variables on the performance of the state civil apparatur in the Department of Education of East Nusa Tenggara Province.
\end{abstract}

Keywords: E-Planning; Leadership style; Working performance; Internal control system

\section{Introduction}

The working performance of the State Civil Apparatur (ASN) is crucial as it has direct impact on the regional development. Therefore, an organization needs capable human resources that can overcome various problems effectively and be able to develop various innovations that can support regional development. Employees are considered as human capital of the organization, which is also a key indicator for the organization to achieve its objectives (Aboazoum et al. 2015). In this case, the measurement of individual performance is important to be done by the organization (Hecht et al. 2019). Organizations need to measure individual performance periodically and objectively (Fehrenbacher et al. 2018).

The department of education is responsible to serve the public interest in all processes of education, and has considerable responsibility since the government transfer of authority of senior and vacational high school to the province. In other words, the regional department of education works 
independently (Law No. 23 year 2014 concerning Regional Government). For this, the State Civil Apparatus is expected to be able to maximally complete the tasks in order to overcome various problems in the education sector. However, based on data of the realization of state budget for the Department of Education of East Nusa Tenggara (see Table 1) indicated that the performance of the education office employees was still not optimal.

Table 1. The realization of state budget for regional Department of Education of East Nusa Tenggara year 2018

\begin{tabular}{llllll}
\hline \multirow{2}{*}{ No } & \multirow{2}{*}{ Programs } & January & August 2018 & \\
\cline { 3 - 5 } & & Budget & Realization & Budget & Realization \\
\hline 1 & Office administration services & $54.81 \%$ & $54.81 \%$ & $39.15 \%$ & $53.79 \%$ \\
2 & Apparatus facilitation enhancement & $74.45 \%$ & $76.43 \%$ & $66.42 \%$ & $68.26 \%$ \\
3 & Performance and financial reporting system & $63.00 \%$ & $65.00 \%$ & $23.90 \%$ & $65.00 \%$ \\
4 & Education quality enhancement & $54.37 \%$ & $60.04 \%$ & $49.68 \%$ & $56.09 \%$ \\
5 & Education services management & $63.00 \%$ & $65.00 \%$ & $60.37 \%$ & $65.00 \%$ \\
6 & Special edication and services & $61.45 \%$ & $24.55 \%$ & $62.17 \%$ & $69.13 \%$ \\
\hline
\end{tabular}

Source: Department of Education of East Nusa Tenggara (2018)

The data from 2018 demonstrated that the realization of many programs did not reach the target. Economic Observer Daniey Adi Purwanto said that there are several factors that lead to the low realization of budgets, including weak budget planning, low capacity to absorb the program planning, and weak or unripe government program and project planning. In addition, other factors includes inappropriate work schedules and the difficulties in execution.

Public organizations that use performance measurement system are consistently able to outperform organizations that keep doing performance measurements without regard to the programs implemented (Speklé \& Verbeeten, 2013). This means that every measurement of employee performance must be adjusted to the activities that have been running in the organization, so that they can see the ability of employees to implement various programs. The Law of the Republic of Indonesia No 5 year 2014 concerning the State Civil Apparatus contains the obligations and prohibitions for ASN. In addition, it also contains of disciplinary penalties that can be imposed on ASN who are proven to have committed violations. The imposition of disciplinary penalties is intended to foster ASN to be more disciplined and to improve themselves to work better.

The performance of the State Civil Apparatur is influenced by various factors, both internal and external. E-planning program quality, internal control systems and leadership styles are the examples of internal factors that affect the performance of the State Civil Apparatur. This study used the performance theory as theoretical basis. Performance theory is used as a basis for explaining the factors that influence the working performance of State Civil Apparatur. Performance is a function or interaction of the dimensions of capacity, willingness and opportunity (Blumberg \& Pringle, 1982). This theory explains that information systems, leadership, and internal control systems affect employee performance.

Those variables have been studied in previous studies. However, there is a research gap in terms of the result, theoretical basis and the variables. Regarding the quality of E-planning program, Nugroho (2016) and Rakhmansyah et al. (2014) found an idea that the information and technology has a positive effect on the employee performance. However, both studies did not use the E-planning program quality as the variable, but information technology. These studies also did not examine the internal control system and leadership styles. Furthermore, Taradipa (2015) investigated the influence of the internal control system on employee performance, but focuses on private companies that already have good internal control procedures. Performance-related research has also been carried out by Kawedar (2015) who used the theory of social behavior as the theoretical basis and explained that performance theory only focuses on individuals as determinants. Whereas in the performance theory, there are many variables that affect 
the performance of the employee and not only focus on the individual. This study wanted to prove that performance theory has other variables that can improve the performance of the State Civil Apparatur. In addition, this study also aimed to investigate the impact of the quality of E-planning program, the implementation of internal control systems and leadership styles on the performance of the state civil apparatus. The focus of this study was on the performance of state civil apparatus of the Department of Education, East Nusa Tenggara province.

\section{Method}

This research is an Explanatory Research using Quantitative method. The population in this study were 100 employees of Department of Education of East Nusa Tenggara province. Furthermore, the sampling technique used was Systematic Random Sampling, and obtained a total sample of 78. Primary data were obtained directly from respondents using questionnaire with Likert scale. The independent variables consisted of the quality of E-planning program $\left(\mathrm{X}_{1}\right)$, the implementation of the internal control system $\left(\mathrm{X}_{2}\right)$ and leadership style $\left(\mathrm{X}_{3}\right)$, while the dependent variable was the performance of the state civil apparatus (Y). The data analysis implemented was Partial Least Square (PLS) on the program of SmartPLS 3.2.8. Data analysis was performed to prove the research hypotheses:

H1 : The quality of E-planning program has a positive impact on the performance of state civil apparatus.

H2 : The implementation of internal control system has a positive impact on the performance of state civil apparatus.

H3 : Leadership style has a positive impact on the performance of state civil apparatus.

\section{Result}

Pilot Test

The pilot test was conducted to test the validity and reliability of the questionnaire to be used for research. The questionnaire was distributed to employees of the East Nusa Tenggara Provincial Education Office and randomly selected from a variety of 53 questionnaires. The pilot test results are described as follows:

Table 2. The result of pilot test

\begin{tabular}{|c|c|c|c|c|c|c|c|}
\hline Variabel & AVE & $\begin{array}{l}\text { Factor } \\
\text { Loading }\end{array}$ & Communality & $\begin{array}{l}\text { Cross } \\
\text { Loading }\end{array}$ & $\begin{array}{l}\text { R } \\
\text { Square }\end{array}$ & $\begin{array}{l}\text { Cronbach's } \\
\text { alpha }\end{array}$ & $\begin{array}{l}\text { Composite } \\
\text { Reliability }\end{array}$ \\
\hline $\mathbf{X 1}$ & 0,627 & 0,790 & 0,627 & 0,793 & \multirow{4}{*}{0,818} & 0,927 & 0,938 \\
\hline $\mathrm{X} 2$ & 0,725 & 0,850 & 0,725 & 0,851 & & 0,980 & 0,981 \\
\hline $\mathbf{X 3}$ & 0,766 & 0,871 & 0,766 & 0,875 & & 0,938 & 0,951 \\
\hline $\mathbf{Y}$ & 0,707 & 0,826 & 0,707 & 0,841 & & 0,953 & 0,960 \\
\hline
\end{tabular}

Source: Research data (2019)

Based on the results of the convergent validity test by looking at the factor loading value, it can be seen that all variables have a value of 0.7 , so that they have met the requirement in the convergent validity test. In addition, the results of the discriminant validity test and reliability, it has also fulfilled the predetermined rule of thumbs (0.7). Furthermore, the composite reliability and cronbach's alpha has also fulfilled the predetermined rule of thumbs (>0.6). Table 3 shows the factor loading and cross loading values of each indicators of variables. 
Table 3. Factor Loading and Cross Loading

\begin{tabular}{|c|c|c|c|c|c|c|}
\hline \multirow{2}{*}{ Variable } & \multirow{2}{*}{ Indicator } & \multirow{2}{*}{$\begin{array}{l}\text { Factor } \\
\text { Loading }\end{array}$} & \multicolumn{4}{|c|}{ Cross Loading } \\
\hline & & & $\mathrm{X} 1$ & $\mathrm{X} 2$ & $\mathbf{X 3}$ & $\mathbf{Y}$ \\
\hline \multirow{9}{*}{$\begin{array}{l}\text { Quality of E-Planning } \\
\text { Program (X1) }\end{array}$} & $\mathrm{X} 1.1$ & 0,756 & 0.721 & 0.315 & 0.348 & 0.373 \\
\hline & $\mathrm{X} 1.2$ & 0,756 & 0.810 & 0.171 & 0.180 & 0.331 \\
\hline & $\mathrm{X} 1.3$ & 0,790 & 0.718 & 0.384 & 0.357 & 0.486 \\
\hline & X1.4 & 0,822 & 0.714 & 0.340 & 0.215 & 0.273 \\
\hline & $\mathrm{X} 1.5$ & 0,876 & 0.703 & 0.205 & 0.302 & 0.370 \\
\hline & X1.6 & 0,843 & 0.787 & 0.209 & 0.128 & 0.249 \\
\hline & X1.7 & 0,786 & 0.817 & 0.344 & 0.267 & 0.329 \\
\hline & $\mathrm{X} 1.8$ & 0,781 & 0.796 & 0.355 & 0.221 & 0.291 \\
\hline & X1.9 & 0,702 & 0.843 & 0.179 & 0.179 & 0.304 \\
\hline \multirow{16}{*}{$\begin{array}{l}\text { Implementation of } \\
\text { Internal Control } \\
\text { System (X2) }\end{array}$} & $\mathrm{X} 2.1$ & 0,889 & 0.327 & 0.823 & 0.281 & 0.396 \\
\hline & $\mathrm{X} 2.2$ & 0,916 & 0.303 & 0.848 & 0.284 & 0.433 \\
\hline & $\mathrm{X} 2.3$ & 0,921 & 0.327 & 0.825 & 0.228 & 0.439 \\
\hline & $\mathrm{X} 2.4$ & 0,885 & 0.187 & 0.780 & 0.248 & 0.309 \\
\hline & $\mathrm{X} 2.5$ & 0,886 & 0.156 & 0.803 & 0.131 & 0.345 \\
\hline & $\mathrm{X} 2.6$ & 0,869 & 0.133 & 0.747 & 0.289 & 0.419 \\
\hline & $\mathrm{X} 2.7$ & 0,845 & 0.298 & 0.760 & 0.183 & 0.287 \\
\hline & $\mathrm{X} 2.8$ & 0,830 & 0.345 & 0.746 & 0.348 & 0.377 \\
\hline & $\mathrm{X} 2.9$ & 0,771 & 0.191 & 0.743 & 0.179 & 0.288 \\
\hline & $\mathrm{X} 2.10$ & 0,822 & 0.391 & 0.746 & 0.292 & 0.279 \\
\hline & $\mathrm{X} 2.11$ & 0,809 & 0.383 & 0.735 & 0.175 & 0.395 \\
\hline & $\mathrm{X} 2.12$ & 0,767 & 0.325 & 0.774 & 0.315 & 0.372 \\
\hline & $\mathrm{X} 2.13$ & 0,866 & 0.290 & 0.786 & 0.388 & 0.414 \\
\hline & $\mathrm{X} 2.14$ & 0,770 & 0.256 & 0.726 & 0.294 & 0.404 \\
\hline & $\mathrm{X} 2.15$ & 0,869 & 0.352 & 0.883 & 0.250 & 0.355 \\
\hline & $\mathrm{X} 2.16$ & 0,959 & 0.379 & 0.784 & 0.364 & 0.369 \\
\hline \multirow{6}{*}{ Leadership Style (X3) } & X3.1 & 0,898 & 0.246 & 0.174 & 0.857 & 0.597 \\
\hline & X3.2 & 0,955 & 0.284 & 0.260 & 0.914 & 0.593 \\
\hline & $\mathrm{X} 3.3$ & 0,916 & 0.348 & 0.288 & 0.731 & 0.654 \\
\hline & X3.4 & 0,862 & 0.318 & 0.397 & 0.808 & 0.550 \\
\hline & X3.5 & 0,708 & 0.089 & 0.222 & 0.746 & 0.366 \\
\hline & X3.6 & 0,890 & 0.304 & 0.348 & 0.872 & 0.551 \\
\hline \multirow{10}{*}{$\begin{array}{l}\text { Performance of State } \\
\text { Civil Apparatus (Y) }\end{array}$} & Y1 & 0,793 & 0.239 & 0.349 & 0.438 & 0.713 \\
\hline & Y2 & 0,919 & 0.344 & 0.371 & 0.718 & 0.858 \\
\hline & Y3 & 0,740 & 0.468 & 0.314 & 0.387 & 0.762 \\
\hline & Y4 & 0,916 & 0.356 & 0.322 & 0.673 & 0.871 \\
\hline & Y5 & 0,728 & 0.234 & 0.368 & 0.441 & 0.738 \\
\hline & Y6 & 0,727 & 0.356 & 0.401 & 0.517 & 0.757 \\
\hline & Y7 & 0,936 & 0.476 & 0.453 & 0.585 & 0.921 \\
\hline & Y8 & 0,932 & 0.441 & 0.401 & 0.646 & 0.902 \\
\hline & Y9 & 0,941 & 0.330 & 0.425 & 0.512 & 0.713 \\
\hline & Y10 & 0,722 & 0.408 & 0.467 & 0.542 & 0.826 \\
\hline
\end{tabular}

Source: Research data (2019)

Table 2 demonstrated that the most dominant indicator in the formation of each research variable. Based on table 2, it can be seen that the most dominant indicator in the formation of the E-planning program quality $\left(\mathrm{X}_{1}\right)$ was $\mathrm{X} 1.5$, that the E-Planning program has background formulation based on data mapped, collected, filled, validated, and evaluated according to Permendagri 86 in 2017, in article 6 paragraph 1 . In the variable of the internal control system implementation $\left(\mathrm{X}_{2}\right)$, the most dominant indicator was X2.16, that the purpose of supervision can be used to assess the quality of internal controls. In the leadership style variable $\left(\mathrm{X}_{3}\right)$, the most dominant forming indicator was $\mathrm{X} 3.2$, that the leader was able to provide employment encouragement to employees. Finally, in the variable of the state civil apparatus performance (Y), the dominant indicator was $\mathrm{Y} 9$, namely the ability of employees to cooperate well in the teamwork. 


\section{Hypothesis Testing}

Hypothesis testing was done by testing the inner model or structural model to determine the coefficient values of each variable. The inner model score indicated by the value of t-statistics, and it must be $>1.96$. Table 4 displays the results of the hypothesis test from PLS analysis.

Table 4. The result of hypothesis testing

\begin{tabular}{|l|l|l|l|l|l|l|}
\hline Hypothesis & $\begin{array}{l}\text { Original } \\
\text { Sample }\end{array}$ & $\begin{array}{l}\text { Sample } \\
\text { Mean }\end{array}$ & $\begin{array}{l}\text { Standard } \\
\text { Deviation }\end{array}$ & $\begin{array}{l}\text { Standard } \\
\text { Error }\end{array}$ & t-Statistics & Interpretation \\
\hline$(\mathrm{H} 1)$ X1 -> Y & 0,189 & 0,202 & 0,078 & 0,008 & 2,431 & Accepted \\
\hline (H2) X2 -> Y & 0,220 & 0,226 & 0,081 & 0,004 & 2,701 & Accepted \\
\hline$(\mathrm{H} 3)$ X3 -> Y & 0,548 & 0,540 & 0,083 & 0,000 & 6,639 & Accepted \\
\hline
\end{tabular}

Source: Research data (2019)

Based on table 4, it can be seen that the value of t-statistics for all variables is more than 1.96 and overall is positive. This means that the quality of e-planning program (X1), the application of internal control systems (X2) and leadership style (X3) partially had a positive and significant effect on the performance of the state civil apparatus (Y). Thus, all hypotheses in this study were accepted.

Here is the final diagram of the PLS analysis:

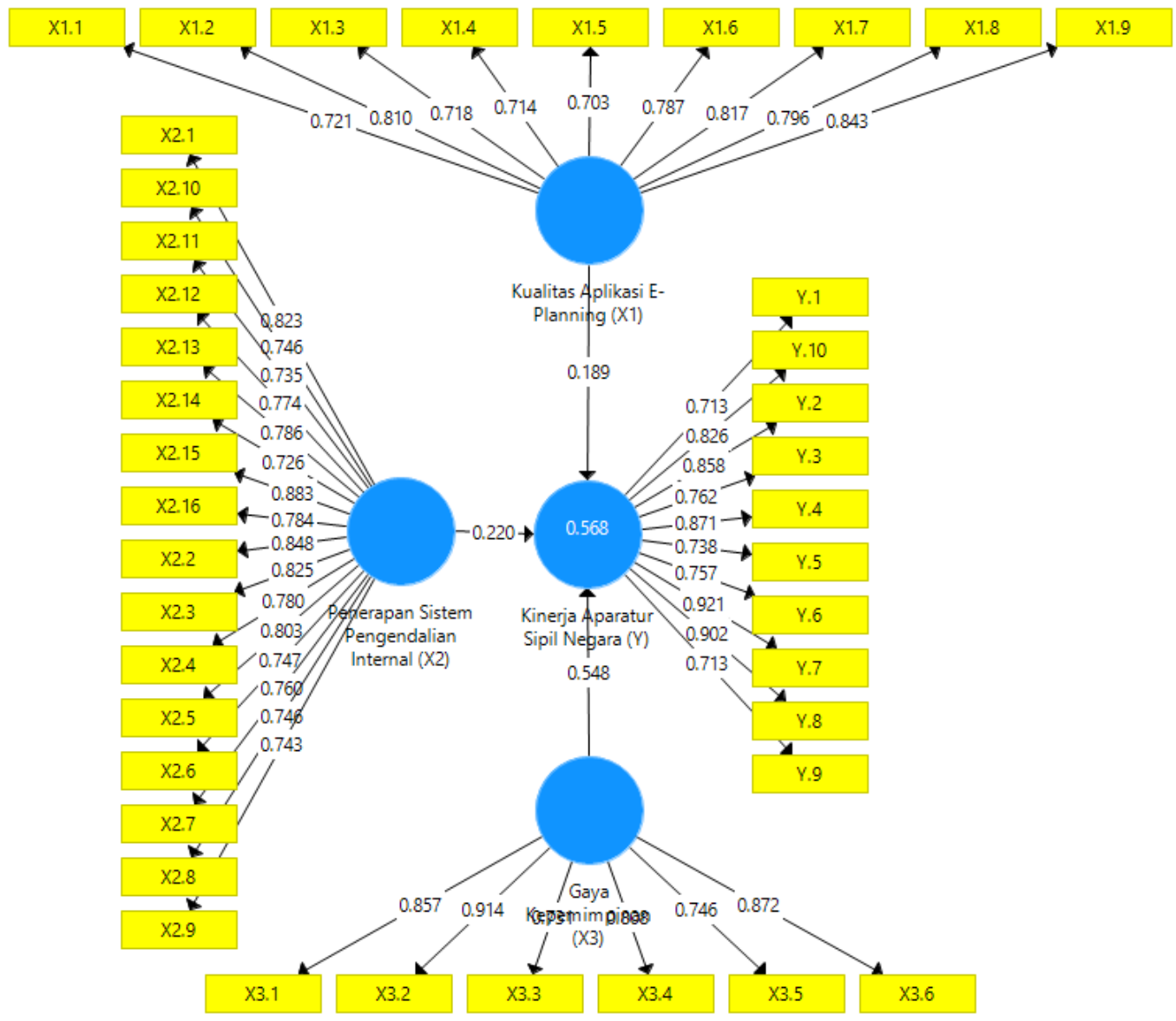

Figure 1. PLS Diagram

Source: Research data (2019) 


\section{Discussion}

The Impact of E-Planning Program Quality on the Performance of State Civil Apparatur

The results showed that the quality of e-planning program had a positive and significant effect on the performance of the State Civil Apparatur. In other words, the higher the quality of the e-planning program, the higher the performance of the State Civil Apparatur. The result of this study supports the idea that information technology systems affect employee performance. Research conducted by Ozman et al. (2016) showed that there was a significant effect of information technology on the performance of employees in Malaysia companies. In addition, Rajakumaran research (2014) also obtained similar result where information technology had a significant effect on employee performance in the Jaffna education department. Researchers found that employee performance improved after being given the introduction of information technology. Furthermore, the study of Abbas et al. (2014) also proved that technology plays an important role in improving employee performance. It was stated that technology can greatly increase the employee productivity and time efficiency. Technology reduces the workload of employees, ensure control of errors, and minimize the occurrence of fraud. The speed and ease of access of information enables bank employees to provide quality services. However, organizations that implement new technologies must also provide appropriate training for employees so that they can improve their performance.

The finding of this study showed that the application of an information system that meets the elements of quality and organizational needs can increase employee interest in employment. In the end, this will affect the performance of employees and the organization as a whole. In this study, researcher also found that many employees did not understand the application of various information systems in various fields of work. Information systems developed in local governments must always be socialized to all elements of the State Civil Apparatur, so that all employees have adequate knowledge regarding the use of new information systems. Employees also need to be given training related to the implementation of new systems within the scope of government so that employee performance can be improved.

\section{The Impact of Internal Control System on the Performance of State Civil Apparatur}

The result of analysis obtained empirical evidence that the implementation of the internal control system had a positive effect on the performance of the State Civil Apparatur. In other words, the better the implementation of the internal control system in the organization, the higher the performance of the State Civil Apparatur. The results of this study support previous studies that provide empirical results that the internal control system had a positive effect on the performance of the State Civil Apparatur. Research conducted by Olufunmilayo (2018) showed that the internal control system affects the performance of employees of manufacturing companies in Nigeria. In addition, Dewi (2012) found that internal control also had a positive and significant effect on the performance of gas station employees in Yogyakarta. The components in internal control such as a good control environment will contribute to create a work atmosphere and encourage the performance of the employees. This finding was even supported by Taradipa (2015) who obtained similar result on the study of employees performance of PT Bank Panin TBK Kendari Branch.

The staff of the Department of Education in East Nusa Tenggara were familiar with various organizational procedures and regulations, but did not fully obey the existing procedures due to the absence of a control and punishment system. Rules were only limited to reprimand and there were no penalties that provide a deterrent effect on apparatus who make mistakes. In addition, evaluation on the employee performance was almost never done. This is due to the report on employee performance results was only needed when the employee is filing a promotion or going to take further education. Periodic assessment of employee performance was almost never done in the Department of Education of East Nusa Tenggara because there was no adequate performance appraisal system in the regional government.

The Impact of E-Planning Program Quality, Implementation of Internal Control System and Leadership Style on the Performance of State Civil 
In addition, the performance report was also SKP-based only, and not yet based on technology. Supervision of the implementation of the internal control system was also still limited to the annual inspection carried out by the inspectorate, and was more focused on financial performance. The supervision on the employee performance was still limited to the presence indicated by fingerprint data on electronic attendance system.

\section{The Impact of Leadership Style on the Performance of State Civil Apparatur}

Based on the the results, it can be stated that the leadership style had a positive effect on the performance of the State Civil Apparatur. The better the leadership style, the better the performance of the State Civil Apparatur. The results of this study are in line with the research of Syafii et al. (2015) which proves that leadership style (transformational and transactional) had a positive and significant effect on employee performance. In addition, Anggraini and Setiawan (2011) also found the results of research that leadership style had an influence on the relationship of budget participation and performance of local government officials. In this case, employees need leaders who are responsive and concern about employee welfare. Every employee needs leaders who are able to give new enthusiasm in the middle of daily routine in the office. These efforts can be done by giving rewards to employees who excel, and also giving punishment to employees who violate the rules.

Data from the field also showed that leaders who are being too hard without any appreciation given to the employee cause the employees to disobey and leave the job. Employees with high workloads also become undisciplined as they are saturated with the conditions at work. In addition, the uneven division of labor also results in some employees not having activities to do. As a solution, the organization needs a type of leader with good discipline and able to implement the system of reward and punishment. Furthermore, good leaders are also willing to go down directly for monitoring and helping employees. Other than that, leaders should also routinely organize various educational and interesting organizational activities for employees to refresh the mind and recharge the work spirit. Altogether, this will enhance the performance of employee.

\section{Conclusion}

The results of this study have provided empirical evidence that the quality of e-planning program, implementation of internal control systems, and leadership styles had a positive and significant impact on the performance of the State Civil Apparatur. Regarding the quality of E-planning program, the government needs to provide information and training for the employees so that they can run the system properly. In addition, it also needs to maintain the quality of the system being run. Regarding the internal control system, the control system in each Regional Device Organization is important to be improved. An adequate internal control system will be able to direct employees so they do not disobey the main task. Furthermore, the leadership styles was proven to have a positive and significant effect on employee performance. Therefore, the leaders of the organization need to apply leadership styles that are appropriate to the work environment. Leaders must have a firm attitude and able to motivate employees to enhance the work performance.

\section{References}

Abbas, J., Muzaffar, A., Mahmood, H., Ramzan, M., \& Rizvi, S. (2014). Impact of technology on performance of employees (a case study on Allied Bank. World Applied Sciences Journal, 29 (October, 2016), 271-276. https://doi.org/10.5829/idosi.wasj.2014.29.02.1897. 
Aboazoum, H. M. E., Nimran, U., \& Musadieq, M. Al. (2015). Analysis Factors Affecting Employees Job Performance in Libya. Journal of Business and Management (IOSR-JBM), 17(7), 42-49. https://doi.org/10.9790/487X-17714249.

Anggraini, I., \& Setiawan, A. R. (2011). Pengaruh Komitmen Organisasi dan Gaya Kepemimpinan Terhadap Hubungan Partisipasi Anggaran dan Kinerja Aparat Pemerintah Daerah. Jurnal Akuntansi Multiparadigma, 2(2), 294-309. https://doi.org/10.18202/jamal.2011.08.7122.

Blumberg, M., \& Pringle, C. (1982). Opportunity Organizational Theory Work. Academy of Management Review, 7(4), 560-569.

Fehrenbacher, D. D., Schulz, A. K., \& Rotaru, K. (2018). The moderating role of decision mode in subjective performance evaluation. Management Accounting Research, (March 2016), 110. https://doi.org/10.1016/j.mar.2018.03.001.

Hecht, G., Newman, A. H., \& Tafkov, I. D. (2019). Managers 'strategic use of discretion over relative performance information provision and implications for team-members ' effort. Management Accounting Research, (July 2018), 1-18. https://doi.org/10.1016/j.mar.2019.01.001.

Kawedar, W. (2015). Pengaruh Penganggaran Partisipatif, Remunerasi, Dan Karakteristik Demografi Terhadap Kinerja Manajerial Dengan Berbagi Pengetahuan Sebagai Variabel Mediasi. Brawijaya Malang.

Nugroho, N. (2016). Pengaruh Penggunaan Teknologi Informasi Terhadap Kinerja Karyawan. Duta.Com ISSN, 11(September 2016), 2086-9436.

Olufunmilayo, A. A. (2018). Effect of Internal Control System on Employee Performance of Small-Scale Manufacturing Enterprises in Ondo State, Nigeria. Human Resource Research, 2(1). https://doi.org/10.5296/hrr.v2i1.13016.

Osman, S., Shariff, S., \& Lajin, M. (2016). Does Innovation Contribute to Employee Performance? Procedia - Social and Behavioral Sciences, 219, 571-579.

Peraturan Menteri Dalam Negeri Republik Indonesia Nomor 86 Tahun 2017. Tata Cara Perencanaan, Pengendalian dan Evaluasi Pembangunan Daerah, Tata Cara Evaluasi Rancangan Peraturan Daerah Tentang Rencana Pembangunan Jangka Panjang Daerah Dan Rencana . (n.d.).

Rajakumaran, T. (2014). Impact of Information Technology on employees 'Performance in Education Department , Jaffna Zone. Indian Journal of Research in Management, Business and Social Sciences (IJRMBSS), 2(1), 2319-2321.

Rakhmansyah, A., Musadieq, M. Al, \& Susilo, H. (2014). Pengaruh Penggunaan Teknologi Informasi Terhadap Kinerja (Studi pada Karyawan PT . PLN Area Madiun). Jurnal 
Adiministrasi Bisnis, 14(1), 1-9.

Speklé, R. F., \& Verbeeten, F. H. M. (2013). The use of performance measurement systems in the public sector: Effects on performance. Management Accounting Research, 1-16. https://doi.org/10.1016/j.mar.2013.07.004.

Syafii, L., Thoyib, A., Nimran, U., \& Djumahir. (2015). The Role of Corporate Culture and Employee Motivation as a Mediating Variable of Leadership Style related with the Employee Performance (Studies in Perum Perhutani). Procedia - Social and Behavioral Sciences, 211, 1142-1147. https://doi.org/10.1016/j.sbspro.2015.11.152.

Taradipa, P. S. (2015). Pengaruh Pengendalian Intern Terhadap Kinerja Karyawan studi kasus pada PT.Bank Panin Tbk cabang Kendari. Jurnal Akuntansi, 1(1), 2-13.

Undang-Undang No 23 Tahun 2014 Tentang Pemerintah Daerah.

\section{Copyrights}

Copyright for this article is retained by the author(s), with first publication rights granted to the journal.

This is an open-access article distributed under the terms and conditions of the Creative Commons Attribution license (http://creativecommons.org/licenses/by/4.0/). 